\title{
Satisfaction of nurses with a training course for the operationalization of protocol on pressure ulcers
}

\author{
Satisfação de enfermeiros com curso de formação para operacionalização de protocolo \\ sobre úlcera por pressão
}

\section{Satisfacción de enfermeros con curso de formación para funcionamiento de protocolo sobre úlcera por presión}

Mayara Vasconcelos Santos ${ }^{1}$, Phamela Vieira Cerqueira ${ }^{1}$, Elaine Cristina Carvalho Moura ${ }^{1}$, Grazielle Roberta Freitas da Silva ${ }^{1}$, Lariza Martins Falcão ${ }^{1}$

Objective: to identify the degree of satisfaction of nurses with a training course for operationalization of protocol on pressure ulcers. Methods: a descriptive exploratory study made in a philanthropic hospital in the northeast of Brazil. An instrument on satisfaction was applied to 21 participant nurses of the course on pressure ulcer based on care protocol. Results: young adults predominated (23-33 years old), female (87.5\%), with significant participation in events, courses and research activities $(81.0 \%)$, and $19.0 \%$ of research publication. The overall rate of satisfaction with the course made at the workplace was $84.34 \%$. Conclusion: when the fundaments of practice based on evidence were cleared, the rate of satisfaction of the professionals who participate in permanent education activities is high, which makes clinical protocol operationalization possible.

Descriptors: Personal Satisfaction; Education, Continuing; Protocols; Nursing.

Objetivo: identificar o grau de satisfação de enfermeiros em participar de formação para operacionalização de protocolo sobre úlcera por pressão. Métodos: estudo descritivo exploratório, realizado em um hospital filantrópico do nordeste do Brasil. Foi aplicado instrumento sobre satisfação para 21 enfermeiros participantes de curso sobre úlcera por pressão fundamentado por protocolo assistencial. Resultados: predominaram jovens adultos (23-33 anos), sexo feminino (87,5\%), com participação expressiva em eventos, cursos e atividades de pesquisa (81,0\%), e 19,0\% de publicação de pesquisa. 0 índice global de satisfação com o curso realizado em ambiente de trabalho foi $84,34 \%$. Conclusão: quando esclarecidos os fundamentos da prática baseada em evidência, o índice de satisfação dos profissionais que participam de ações de educação continuada é elevado, o que possibilita operacionalizar protocolos clínicos.

Descritores: Satisfação Pessoal; Educação Continuada; Protocolos; Enfermagem.

Objetivo: identificar el grado de satisfacción de enfermeros en participar de formación para funcionamiento de protocolo sobre úlceras por presión. Métodos: estudio exploratorio, descriptivo, en un hospital filantrópico en el noreste del Brasil. Fue instrumento aplicado sobre satisfacción de 21 participantes del curso de enfermería basado en el protocolo de atención. Resultados: predominaron jóvenes adultos (23-33 años), sexo femenino (87,5\%), con participación expresiva en eventos, cursos y actividades de investigación (81,0\%), y 19,0\% de publicaciones de investigación. El índice general de satisfacción con el curso realizado en el lugar de trabajo fue $84,34 \%$. Conclusión: cuando aclarados los fundamentos de la práctica basada en evidencia, el índice de satisfacción de los profesionales que participan de acciones de educación continua es alta, lo que permite funcionar protocolos clínicos.

Descriptores: Satisfacción Personal; Educación Continua; Protocolos; Enfermería.

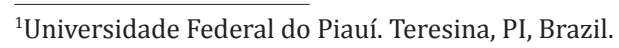




\section{Introduction}

In Brazil, the National Policy on Permanent Education in Health is understood as learning at work and for the work, where learning and teaching are incorporated into the daily lives of the organizations and into the service ${ }^{(1)}$.

In this process of formation the importance of aspects of satisfaction of the worker is highlighted, facing the actions experienced and to be performed at the workplace. Satisfaction in this study is a conjunction of beneficial sensations that establish a condition of emotional pleasure from the analysis that a person makes on to what extent his work allows the assistance of his objectives and values and makes them easier.

Studies reinforce the importance of Permanent Education as an essential factor for the transformation of the professional practice of nurses, bearing in mind that actions of Permanent Education activities stimulate the debate and the improvement of the service through new proposals, besides providing the possibility of acquiring new knowledge to the health professional as well as being its multiplier ${ }^{(2-3)}$.

In order to comply with the needs of the market of the current work, the actions of Permanent Education incorporate teaching and learning to the daily lives of the organizations and to the social and working practices, in the actual scenario where they occur. In this context, measures of control of total quality have been implemented to act specifically on reducing variability of the practice of care, especially the practice guidelines, expert advice, professional groups and, more recently, care protocols ${ }^{(4)}$.

Protocols are conducts developed with systematic method to help decision taking in order to improve clinical outcomes and allow more patients to benefit from scientific knowledge on the best practices available. The operationalization of care protocols can promote standardization of conduct, leading to an improvement of the efficiency of care ${ }^{(5)}$.

In this sense, this study highlights the importance of the operationalization of care protocols for prevention and treatment of pressure ulcers once the incidence and prevalence of pressure ulcers are appointed by the World Health Organization as indicators of the care rendered ${ }^{(6)}$. From this perspective this study was made to identify the degree of satisfaction of nurses attending a training course for the operationalization of protocol on pressure ulcers.

\section{Method}

It is a descriptive exploratory study with a quantitative approach, made in a philanthropic hospital of the state of Piauí, in the northeast of Brazil, in October 2014. Courses of Permanent Education were provided based on the clinical protocol for prevention and treatment of five types of wounds: pressure ulcers, vasculogenic ulcers, oncological wounds, surgical wounds and burns, aiming at its operationalization. This protocol was developed in 2010, published in 2012 and updated in 2014 through integrative reviews.

There were 35 nurses registered. On the day of the presentation on the topic of prevention and treatment of pressure ulcers, 21 of those enrolled attended, given that the demand was spontaneous. The course was offered in the philanthropic hospital and eight places were aimed at nurses from county hospitals.

The participants of the study were all the nurses working in a philanthropic institution and hospitals of the county of Teresina. The sample included participants who had enrolled in the course on the operationalization of clinical protocol for the prevention and treatment of pressure ulcers. The criteria of inclusion were: being a nurse in the institutions in which the course was offered; join the course on the implementation of clinical protocol.

Data were collected in October 2014, using an instrument of data collection based on the content of treatment and prevention of pressure ulcers, consisting of two parts, the first with social demographic 
data, consisting of these: age, sex, education (undergraduate and graduate), marital status, professional and schooling information as well as information on the production and publishing of scientific work, time being a nurse, participation in courses on prevention or treatment of pressure ulcers, participation in specific events on the topic or on wounds and publications in the field of pressure ulcers. The second part consisted of 17 statements on satisfaction as to the structure, methodology of the course and safety in the operationalization of the Protocol, as well as aspects related to the permanent Education.

The second part of the instrument was answered using the scale of Likert of three points: 1 . "dissatisfied", 2. "neither dissatisfied, nor satisfied" and 3."satisfied" in order to identify satisfaction aiming at the operationalization of the protocol in the daily work after the course where 17 was the minimum score and 51 the maximum score. Evaluations with best level of response and $p$ value less than 0.05 were considered satisfactory.

Data were analyzed by Statistical Package program for Social Sciences ${ }^{\circledR}$ version 18.0. The Shapiro-Wilk normality test was used to verify the distribution of continuous quantitative variables. Each item was tested for normal distribution and the $t$ test of student was applied to have a sample in the analysis of the parametric data. Quantitative variables were presented as an average ( \pm standard deviation), minimum and maximum, and the category variables were presented in proportion.

The study was approved by the Committee of Ethics and Research of the Federal University of Piauí, under legal opinion number 880,594.

\section{Results}

Of the 21 participating nurses, 18 (85.7\%) were female. The average age was 26.9 years, ranging from 23 to 33 years. Regarding marital status, 17 $(81.0 \%)$ were single. Regarding university education 9 (42.9\%) completed the course between 2012 and
2014. With 5-10 years experience as a nurse there were only 3 (14.3\%), 2-5 years of operation 9 (42,9\%) and less than 2 years, 9 (42.9\%). As to the university $16(76.2 \%)$ had their education in private institutions.

Regarding the Permanent Education of participants $10(47.6 \%)$ had pos-graduation stricto sensu and $2(9.5 \%)$ had post-graduation lato sensu. Among the 21 participants, there were 14 (66.7\%) working in a philanthropic institution and 7 (33.4\%) in public institutions and among all the function of assistant nurse was performed by 18 (85.7\%) of them.

Table 1 presents data concerning the participation in events related to pressure ulcers, publishing of scientific work and participation in groups related to wounds.

Table 1 - Distribution of the Frequency according to the participation of the nurses in events, courses, groups, and conducting research related to pressure $(\mathrm{n}=21)$

\begin{tabular}{|c|c|}
\hline Variables & $\mathrm{n}(\%)$ \\
\hline \multicolumn{2}{|l|}{$\begin{array}{l}\text { Participation in scientific events (journeys, symposiums, } \\
\text { congresses) }\end{array}$} \\
\hline Yes & $17(81.0)$ \\
\hline No & $4(19.0)$ \\
\hline \multicolumn{2}{|l|}{$\begin{array}{l}\text { Participation in activities concerning the research } \\
\text { during graduation course }\end{array}$} \\
\hline $\begin{array}{l}\text { Institutional program of scholarships of scientific } \\
\text { initiation }\end{array}$ & $5(23.8)$ \\
\hline Publishing of works & $5(23.8)$ \\
\hline Did not participate & $11(52.4)$ \\
\hline \multicolumn{2}{|l|}{ Participation in events on pressure ulcers in the last 5 years } \\
\hline Yes & $13(61.9)$ \\
\hline No & $8(38.1)$ \\
\hline \multicolumn{2}{|l|}{$\begin{array}{l}\text { Participation in courses on prevention and treatment of } \\
\text { pressure ulcers }\end{array}$} \\
\hline Yes & $20(95.2)$ \\
\hline No & $1(4.8)$ \\
\hline \multicolumn{2}{|l|}{$\begin{array}{l}\text { Participation in committees or groups of study of the } \\
\text { institution }\end{array}$} \\
\hline Yes & $17(81.0)$ \\
\hline No & $4(19.0)$ \\
\hline \multicolumn{2}{|l|}{$\begin{array}{l}\text { Publishing in the area of pressure ulcers in scientific } \\
\text { journals }\end{array}$} \\
\hline Yes & $4(19.0)$ \\
\hline No & $17(81.0)$ \\
\hline Total & $21(100.0)$ \\
\hline
\end{tabular}


Of the total number, $11(52.4 \%)$ did not participate in activities related to the research during graduation and $10(47.6 \%)$ performed works involving research. The participation in scientific events was significant involving 17 (81\%) of the participants, 13 (61.9\%) participated in specific events on pressure ulcers. Almost all participants (95.2\%) took other courses on prevention and treatment of pressure ulcers and 17 (81.0\%) participate in committees or groups of institutional studies, however, only 4 $(19.0 \%)$ had publications in the field of pressure ulcers in scientific journals.

Table 2 presents data on the satisfaction of nurses with training courses for the operationalization of protocol on pressure ulcers.

Table 2 - Distribution of the frequency, rates ( \pm standard deviation) of the satisfaction of the nurses $(\mathrm{n}=21)$ with the course for operationalization of protocol on pressure ulcers

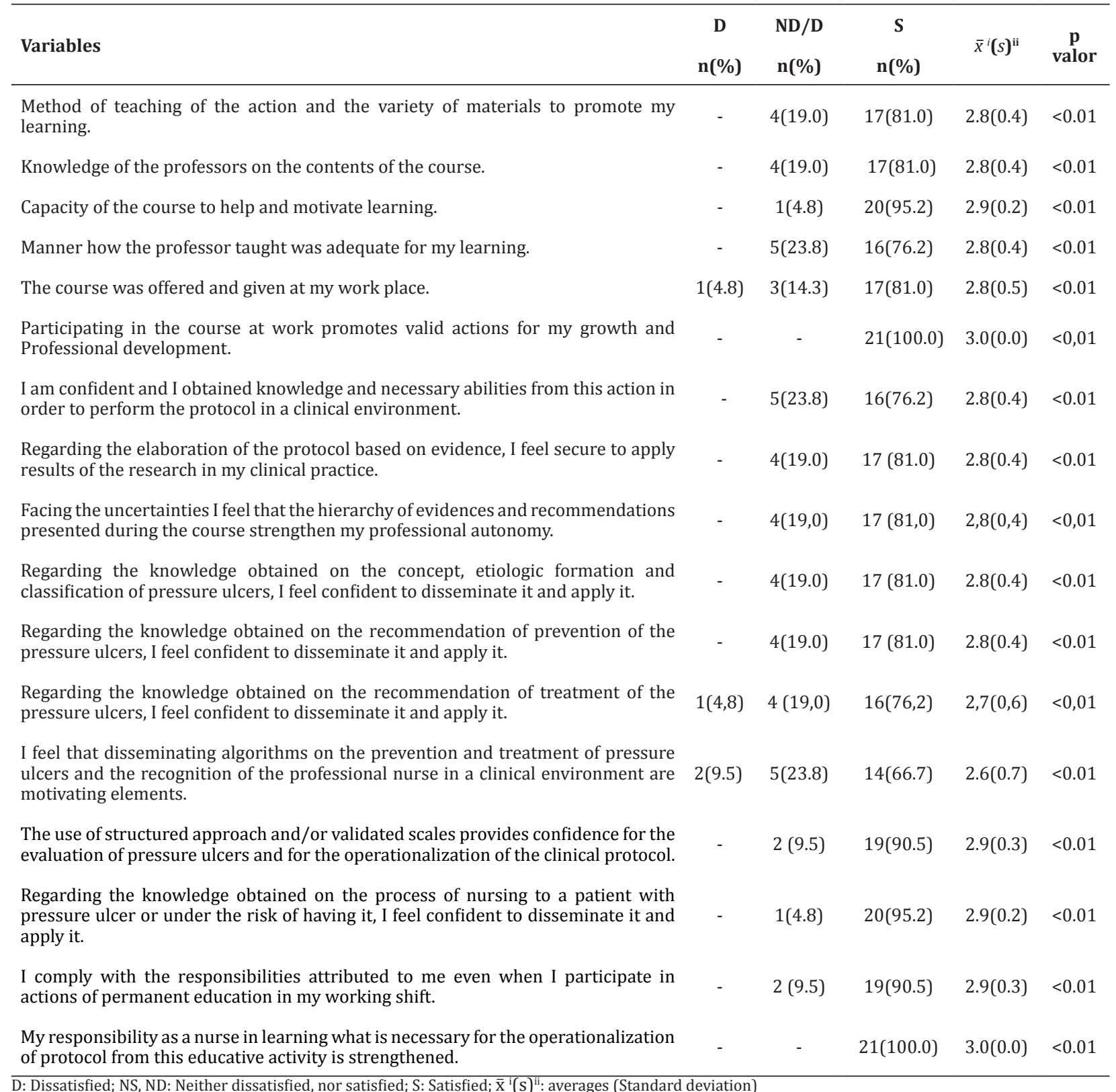

D: Dissatisfied; NS, ND: Neither dissatisfied, nor satisfied; S: Satisfied; $\overline{\mathrm{X}}^{\mathrm{i}}(\mathrm{S})^{\mathrm{ii}}$ : averages (Standard deviation) 
According to Table 2, the participants felt dissatisfied with only three statements related to the place of the course, to the confidence in disseminating knowledge on the treatment and to the motivation in disseminating algorithms. Only two statements were not marked with the "neither satisfied nor dissatisfied". The participants showed satisfaction in all statements, in two of them the choice was unanimous and they are related to the course for bringing growth and professional development and for the professionals to feel their responsibility strengthened after the course with the operationalization of the protocol.

Of the $17,2(11.7 \%)$ to $5(29.4 \%)$ items concentrated participants who were neither satisfied nor dissatisfied, which expresses tendency to dissatisfaction. These figures, if added to the positive extreme of response (satisfied), would represent an average of $93.5 \%$ and if added to the negative extremes of response, they would represent $27.3 \%$. The p-value was $<0.01$ showing a very strong evidence against null hypothesis, increasing the significance of the study. The level of overall satisfaction after the course, facing all the criteria evaluated was $84.34 \%$.

\section{Discussion}

Bearing in mind the variety of information and the rapid technological development in healthcare, the need for professionals seeking Permanent Education is observed, whether under the perspective of Permanent Education or courses of specialization, master's degree and doctorates. Thus, the importance of education at work and for the work seemed to be understood by the professionals. In a study with the aim of discussing the concept of Permanent Education among nurses at a school hospital was concluded that it is not enough to be aware of the need for continuity of learning, nurses need to be motivated to become responsible for their learning ${ }^{(7)}$. Dualities in perception and expectations affect the adhesion in Permanent Education activities and can justify the fact that although 35 participants were enrolled, only 21 attended the course.

This research did not assess the differences between men and women, but a greater number of women were identified, once this is still the sex of most of the nursing professionals in the health services. A research aimed at identifying the network configuration of social relations of adults and their satisfaction showed that women of all ages have more characteristics related to feelings of satisfaction in social relationships than men, such as less aggressiveness, more sympathy and more involvement (8). Involvement with permanent education actions needs this enthusiasm to promote sufficient social ties and satisfaction to result in multipliers able to motivate the implementation of actions.

The evidences of the above mentioned gender can be linked with the predominance of young adults who can be related to the job satisfaction of health professionals. A study of quantitative and descriptive approach which analyzed the influence of gender and age found that in younger professionals the desire to learn and gain experience can make them evaluate as positive the aspects which can be seen by older professionals as cause of dissatisfaction (9). These social demographic characteristics maintain the high level of satisfaction of the research participants.

It is highlighted that the National Policy on Permanent Education in Health was established in February 2004 and implemented in 2007. This aimed at establishing the learning at work, where teaching and learning should be incorporated into the daily lives of organizations and service and is based on the critical reflection about the actual practices of professionals at work in services ${ }^{(1)}$.

Most of the participants in this research completed the graduation after implementation of the policy, therefore, they are more familiarized with the prerogatives of the policy, and aspects that can relate to the high degree of satisfaction observed in this study. Once, since the implementation of this policy, the 
health department aimed at stimulating, monitoring and regulating the use of health services in the scope of management curricular and extracurricular activities of technical, graduation and post-graduation courses in health, besides articulating, along with the teaching institutions, changes in their courses, according to the needs of the Unified Health System, stimulating an attitude of health responsibility.

It was found, however, that participation in events and courses on pressure ulcers, during or after graduation demonstrated the approach with activities related to research as well as extensive activities in groups on wounds, though there may be difficulties in understanding and implementing protocols because it requires knowledge concerning the design of researches with severe methodology. That occurs because the practice based on evidence incorporates the best evidence from the well designed studies to the praxis as well as the data of the patient together with the preference, values of the client and the performance and capacity of the health professional to apply the evidence ${ }^{(10)}$. Thus, a limited understanding of research design and levels of evidence, would be a barrier to the operationalization of protocols and especially the use of results of reliable research in care practice.

One of the tools that enable practice based on evidence in the hospital environment is the use of clinical care protocols once they are elaborated from the results of reliable research. The lack of standardization of actions means frailty, leading to a wide variation in the ways of doings. It is desirable for the nurses to be prepared and able to deal with issues and activities related to the research. The language of the protocols justifies the need of professionals with knowledge ${ }^{(11)}$.

In the present study although there are nurses engaged in master's degree courses (stricto sensu) the scientificproduction oftheparticipantsislimited,which can justify, for example, misunderstanding algorithms involving a course of action of understanding as a graphic based on recommendations and evidence of the Protocol and thus essential for operationalization of the same.

Poor understanding of algorithms reveals the perception that conceptually the intermediate points of the response scale refers to a neutral level between satisfaction and dissatisfaction. So, the one who is neutral does not show any agreement ${ }^{(12)}$. Therefore, adding "neither satisfied nor dissatisfied" to the extreme negative the highest levels of dissatisfaction are revealed, that although they do not reduce the the average percentage of satisfaction, this is relevant for the analysis of the limitations regarding the performance of practices based on evidence in the area of nursing for the concrete operationalization of the protocol on pressure ulcer, as follows:

Regarding the methodology of the course (items 1, 2 and 4), the average was $20.6 \%$ dissatisfied and $79.4 \%$ satisfied. These items are related to the method and to the materials used in action, to the domain and the manner of conduction of the lecturers on the content of the course. Studies dealing with issues related to Andragogy (adult education) and Permanent Education in the training of health professionals agree that the success of learning involves the use of appropriate strategies, the path used was related to Andragogy with direct involvement of the participants, which is consistent with the high percentage of satisfaction, its use in the training of nurses is critical to job performance ${ }^{(13-14)}$

As for the aspects of education in the workplace (items 3, 5, 6 and 17), the average satisfaction was $94 \%$, and the items 6 and 17 all participants considered to be fully satisfied, indicating that they recognize the importance of Permanent Education to promote professional growth and development as well as strengthening the responsibility as nurses ${ }^{(15)}$.

On the operationalization of the Protocol (items 7 to 16 ), there was an average satisfaction of $81.9 \%$ and $18.1 \%$ of dissatisfaction. The item that deals with the use of algorithms for pressure ulcer prevention 
and treatment showed the highest percentage of dissatisfaction (33.3\%) algorithm is a finite sequence of instructions and organized in a logical way to solve a particular task or problem. The development of an algorithm establishes a pattern of behavior that should be followed to achieve a favorable outcome ${ }^{(16)}$. It is noticed that the understanding of the algorithms presupposes certainty in the application of prevention and treatment recommendations contained in the protocol.

It is also highlighted that the practices of Permanent Education in terms of operationalization of care protocols, promote safety in using them and generate a personal responsibility to what should be done, thus ensuring a better quality of the service rendered. Thus, the activities developed during the permanent education strategy on health serve as stimulus, generate job satisfaction and awaken the personal interest of each member of the team by the professional qualification. The need for the commitment of the leadership of the health services is strengthened when investing in training their employees, besides encouraging participation in activities of this nature.

\section{Conclusion}

A high level of satisfaction of the nurses with the action of the proposed permanent education was identified, suggesting that the education at work and for the work enables the operationalization of the clinical protocol. It is worth highlighting mentioning the importance of clarifying the conceptual basis of the practice based on evidence which supports protocols and intensify the approach of care nurses with reliable research results. Thus there will not only be more satisfaction in the operationalization of protocols but also desirable attitudes towards care praxis of excellence and quality to people with pressure ulcer or under the risk of it.

\section{Collaborations}

Santos MV, Cerqueira PV and Moura ECC contributed with the planning of the project, analysis and interpretation of the results, writing and critical revision of the contents and approval of the final version. Silva GRF and Falcão LM contributed with the critical revision of the intellectual content and approval of the final version to be published.

\section{References}

1. Ministério da Saúde (BR). Portaria GM/MS no 278, de 27 de fevereiro de 2014. Institui diretrizes para implementação da Política de Educação Permanente em Saúde. Brasília: Ministério da Saúde; 2014.

2. Silva LAA, Ferraz F, Lino MM, Backes VMS, Schmidt SMS. Educação permanente em saúde e no trabalho de enfermagem: perspectiva de uma práxis transformadora. Rev Gaúcha Enferm. 2010; 31(3):557-61.

3. Morais Filho LA, Marinho CSR, Backes VMS, Martini JG. Continuing healthcare education: a strategy to connect teaching and services. Rev Rene. 2013; 14(5):1050-60.

4. Falkenberg MB, Mendes TPL, Moraes EP, Souza EM. Educação em saúde e educação na saúde: conceitos e implicações para a saúde coletiva. Ciênc Saúde Coletiva. 2014; 19(3):847-52.

5. Prazeres SJ. Tratamento de feridas: teoria e prática. Porto Alegre: Moriá; 2009.

6. Areosa LA, Martínez MB, López EM, Morán MJM, Gómez TS. Úlceras por presión: prevención y tratamiento. Barcelona: Ediciones Mayo; 2010.

7. Jesus MCP, Figueiredo MAG, Santos SMR, Amaral AMM, Rocha LO, Thiollent MJM. Permanent education in nursing in a university hospital. Rev Esc Enferm USP. 2011; 45(5):1229-36.

8. Irigaray $\mathrm{TQ}$ Schneider RH. Dimensões de personalidade, qualidade de vida e depressão em idosas. Psicol Estud. 2009; 14(4):759-66. 
9. Carrillo-Garcia C, Solano-Ruiz MC, Martinez-Roche ME, Gómez-Garcia CI. Job satisfaction among health care workers: the role of gender and age. Rev Latino-Am Enfermagem. 2013; 21(6):131420.

10. Melnyk BM, Fineout-Overholt E, Stillwell SB, Williamson KM. Evidence-based practice: Step by step. The seven steps of evidence-based practice: Following this progressive, sequential approach will lead to improved health care and patient outcomes. Am J Nurs. 2010; 110(1):51-3.

11. Aguiar DF, Camacho KG. The daily activity of the nurse in clinical research: an experience report. Rev Esc Enferm USP. 2010; 44(2):526-30.

12. Silva Júnior SD, Costa FJ. Mensuração e escalas de verificação: uma análise comparativa das escalas de Likert e Phrase Completion. Rev Bras Pesq Mark. 2014; 15:1-16.
13. Draganov PB, Friedländer MR, Sanna MC. Andragogiana saúde: estudo bibliométrico. Esc Anna Nery. 2011; 15(1):149-56.

14. Somera EAL, Somera Junior R, Rondina JM. Uma proposta da andragogia para a educação na área da saúde. Arq Ciênc Saúde. 2010; 17(2):101-7.

15. Silva GM, Seiffert OMLB. Educação continuada em enfermagem: uma proposta metodológica. Rev Bras Enferm. 2009; 62(3):362-6.

16. Feijó MKEF, Biolo A, Rabelo-Silva ER. Adaptação e aplicabilidade de um algoritmo de diurético para pacientes com insuficiência cardíaca. Arq Bras Cardiol. 2013; 100(6):553-60. 